\title{
THE INFLUENCE OF THE EXTERNAL AND INTERNAL ENVIRONMENT OF PRIMARY CARE FACILITIES ON THE PREVENTION OF DISEASES OF THE CIRCULATORY SYSTEM
}

DOI: $10.36740 /$ WLek202103213

\author{
Iryna M. Kremsar, Victoria I. Klymenko \\ ZAPORIZHZHIA STATE MEDICAL UNIVERSITY, ZAPORIZHZHIA, UKRAINE
}

\begin{abstract}
The aim: Of the work is analysis of strengths and weaknesses, opportunities and threats of the external and internal environment in primary care facilities for the implementation of preventive measures of cardiovascular diseases (CVDs).

Materials and methods: An analysis of the work of primary health care facilities for the prevention of CVDs, which included external and internal audit, such as analysis of the regulatory framework, human resources, logistics provision, questionnaire of adult population of Zaporozhye region on awareness of factors risk of diseases of the circulatory system and a healthy lifestyle.

Results: Thanks to the adoption of a number of regulations, timely management decisions, it was possible to achieve $100 \%$ provision of medical equipment necessary for the prevention of CVDs, but low staff capacity of doctors with their unsatisfactory level of knowledge about the main CVDs risk factors. instability, pose a serious threat to the further stable development of primary health care and their prevention.

Conclusions: Significant progress had been made in the implementation of preventive measures for CVDs. Against the background of many existing problems.
\end{abstract}

KEY WORDS: primary health care, cardiovascular diseases, prevention, threats, opportunities

Wiad Lek. 2021;74(3 p.II):636-640

\section{INTRODUCTION}

For many decades, changes in primary health care (PHCs) settings on the basis of family medicine has been implementing all over the world in order to ensure the availability and quality of health care. Nevertheless, $50 \%$ of the world's population has limited access to PHC, including the treatment and prevention of chronic noncommunicable diseases (NCD). In order to this, the World Health Organization (WHO) held a Global Conference dedicated to a primary healthcare organization, on which its state and prospects for development in the world were considered [1]. The implementation of primary healthcare on the basis of family medicine has become a priority in Ukraine after the adoption of the resolution of the Cabinet of Ministers of Ukraine № 989 "About comprehensive measures for introducing family medicine into the health care system" became a starting point in reforming the health care system of our country [2].

According to the WHO, diseases of the circulatory system (DCS) have been the leading cause of death worldwide for a half a century. [3]. In different countries of the world the share of CVDs is from $30 \%$ to $65 \%$ [4]. That is why the WHO has declared the main task for the whole world to reduce mortality from CVDs by $25 \%$ by 2025 , and the World Heart Federation - to reduce mortality from DCS by $25 \%$. Almost every third case of a patient's referral to a health care institution (HCI) occurs due to this pathology.
The experience of developed countries shows that the most effective in reducing mortality from CVDs are preventive measures at the population level and secondary prevention. Thus, it is advisable to analyze the external and internal environment of primary care facilities, the main task of which is preventive measures.

\section{THE AIM}

The aim is analysis of strengths and weaknesses, opportunities and threats of the external and internal environment in primary care facilities for the implementation of preventive measures cardiovascular diseases.

\section{MATERIALS AND METHODS}

Medico-social substantiation of the strengths and weaknesses, opportunities and threats of the external and internal environment of primary health care facilities (HCF) of communal ownership was by the analysis of the current legal framework of the organization of work as a health care facility of primary care (PC) is provided as of requirements for its provision, in accordance with the standards of medical care for patients with chronic cardiovascular pathologies, which was as external audit, and on the results of our own research, conditionally defined as an internal audit of the health care facility. Official data 
of the permanent population of Zaporizhia region and its structure were obtained from the Zaporizhia Regional Statistical Office for the purpose of social impact of the external environment, and a survey of adults in the Zaporizhia region on awareness of risk factors of CVDs (3021 questionnaire). For the internal audit, a detailed analysis of two main groups of resources was carried out: logistics of the PHCs, communal forms of ownership and human resources. The information was collected on the basis of 32 primary health care centers of Zaporizhia region, which was a total at the beginning of the retrospective study (2015-2017). During the last three years, decentralization processes (creation of united territorial communities) have been actively started and the number of PHCs providing PC has increased to 48 (as of July 1, 2019). Materials for the analysis of personnel potential were statistical data of copying from $\mathrm{f}$. № 17 «Report on medical personnel for 20 _ years» (112 units).

For studing the logistical support of facilities that provide PHCs, from the list of equipment of the physician was identified equipment that meets the standards for the prevention and treatment of CVDs : tonometer with a set of cuffs, stethoscope, portable otoophthalmoscope, tape measure, blood level monitor set, height meter, medical scales, portable three-channel electrocardiograph. Data on the need were calculated in accordance with the Order of the Ministry of Health of Ukraine dated January 26, 2018 № 148 [5] and data on security for all the above positions in the HCF on the financial statements of the institution. Statistical processing of the obtained material required the formation of a computer database based on Microsoft Excel, where the results of the study were grouped depending on the task of the study, and statistical processing of the results was performed using the program Statistica 10.0. To conduct a comparative analysis in the dynamics, we used the relative values, indicators of equipment and personnel, which are presented in the form of $\mathrm{Me}(25 \% ; 75 \%)$. Estimation of reliability of a difference of the received data in dynamics was estimated by nonparametric methods.

For the systematization of the results of the study, for the strategic planning of threats and opportunities of the enterprise SWOT-analysis was used. SWOT-analysis consists of dividing factors and phenomena into four categories: strengths and weaknesses of the model, opportunities in its implementation and threats associated with its implementation [6].

Due to the fact that the analysis of the internal environment of PHCs providing communal ownership was carried out on the general population of PHCs of Zaporizhia region, and environmental factors are the only ones in the country, the obtained data are representative.

\section{RESULTS}

To ensure the basic functions of primary health care, the Ministry of Health approved the Model Table of Material and Technical Equipment of Health Care Institutions [5] and Individual Entrepreneurs Providing Primary Health
Care and allocated basic and additional lists of equipment and facilities for providing medical services using telemedicine which have been used in many countries for a long period of time. There are only 68 kits for telemedicine in the primary care facilities, which corresponds to $5 \%$ of the provision at January,2020.

An important condition for the quality of primary care and prevention of diseases of the circulatory system is the provision of health care facilities with appropriate equipment fully. According to our data, in 2015 the maximum supply of height meters on average was $47.6(28.9 \div$ $65.3) \%$, which is 2 times lower than required, the supply of tonometers for measuring of arterial pressure ranged from $10 \%$ to $52 \%$. The worst situation was observed with the availability of devices for electrocardiography, when there was only 1 device per establishment in the presence of 10 individuals-entrepreneurs, not taking into account the separate structural units. The lack of motivation of medical workers to ensure preventive work is underlined by the fact that the provision of tapes for measuring waist circumference averaged only $7.7(0 \div 9.6) \%$ in the region against the background of minimal economic costs. In view of the foregoing, management decisions were focused on the needs of the primary health care facility. There were significant changes in the equipment of primary health care facilities in Zaporizhzhia region in 2017, namely: the provision of tonometers with a set of cuffs amounted to $143.4(100.8 \div 176.3) \%$, which is 3.2 times more than in 2015, portable otoophthalmoscopes - $136.8(100.0 \div$ $166.4) \%$, which compared to 2015 - on $121.6 \%$ more, and the least - medical scales - $107.3(100.0 \div 113,6) \%$ and height meters $-110.7(100.0 \div 113.6) \%$. In 2019 , the minimum provision of primary care facilities in the region was on average $107.4(100.0 \div 135.2) \%$ stethoscopes and height meters $108.0(100.0 \div 123.3) \%$. Thus, due to timely management decisions based on a systematic analysis of the material and technical state of the primary care facility with equipment for prevention and treatment of patients with diseases of the circulatory system allowed to achieve this figure of $100 \%$, which became a strong factor in the internal environment of health care facilities.

In order to study the use of this equipment, we analyzed the staff capacity of medical workers (doctors, nurses) of primary health care and study their level of knowledge. Our data showed that the level of provision of doctors during 2017-2019 remains within the statistical error on average $66.1(59.25 \div 81.2) \%$ without a significant difference by districts and cities of Zaporozhzhia region. Stuffing by nurses in the Zaporizhzhia region averages 82.4 (73.1 $\div$ $91.8) \%$, which significantly exceeds the level of provision of doctors on the primary level $(\mathrm{p}<0.05)$, the vast majority of whom are persons under 45 years - $62.0(54.9 \div 73.7) \%$, which indicates a sufficient number of medical workers with nurse education in health care facilities that provide primary care. Analyzes was conducted the enactment of the order of the Cabinet of Ministers of March 28, 2018 № 302 "About approval of the Regulations of the system of continuous professional development of specialists of 
health care" [7]. This order defines the basic organizational principles of continuous professional development throughout the period of professional activity.

Medical and organizational problems of prevention of diseases of the circulatory system are hidden in the insufficient level of knowledge of primary care physicians about the leading risk factors for diseases of the circulatory system, which needs urgent correction and improvement in order to effectively prevent the population [8]. All of the above proves the possibility of the development of the primary level of health care, but the vast majority of elderly and senile age influence on the amount of medical care and the workload of family doctors. Every year there is an increase in the share of the population of older than working age according to the official data of the Zaporizhia Regional Statistical Office, which part in 01.2019 is $28.3 \%$. Even when concluding an agreement between a primary health care institution and the National Health Service of Ukraine, a correction factor of 1,232 for 2020 is envisaged, which provides additional opportunities for the population of this category. At the same time, given the constant annual growth of the elderly population, there is a risk of burden not only on doctors due to chronic non-communicable diseases but also on the budget, because there is a need for constant medication as secondary prevention. Secondary prevention became more accessible after the introduction of the state program "Affordable Medicines", which has been implemented in Ukraine since 2016 [9]. As a result of all implemented measures at the state level, the population's requirements for the quality of medical care are growing, namely the population has low social responsibility for their health and commitment to a healthy lifestyle, which is confirmed by many medical and social studies, including ours [10]. The results of our survey showed that almost $55 \%$ of the adult population believe that they follow a healthy lifestyle, in terms of gender differences, $45.5 \%$ of men and $60 \%$ of women. $93.3 \%$ of the total number of respondents, in their opinion, know some information about risk factors of CVDs., which increases with age and mainly among women, but significant difference in terms of age and gender differences were not found. The lowest level of awareness of risk factors of CVDs is observed in the group of $18-24$ years ( $81.6 \%$ - all together), especially among men $-75.0 \%$, which indicates a lack of control over health policy. Threats for increasing of preventive work at the primary level are created not only by external factors, but the biggest obstacles to this work are in the internal environment, to overcome which today there is a solid basis in the form of strong factors of the internal environment of the PHC. In order to the Law of Ukraine «About state financial guarantees of medical care» [11] ensure rapid and relatively irreversible changes in the system of primary health care (work of the HCF), a number of bylaws have been developed and issued, which confirms the will of the patient (or his legal representative) to choose a physician who will provide him with primary care [12].

Thus, the imperfection of the organizational structure, approaches to the rational use of available limited resourc- es, the optimal organization of primary health care lead to the fact that the same factors not only open opportunities for development, but can also be a threat to development.

\section{DISCUSSION}

An analysis of environmental factors over the past 10 years allows us to assert that, in the conditions of several changes of the political structure and government in the country, rapid reform of the health care system was initiated. The modern health care system of Ukraine became characterized by an active transition from the budget-insurance to the market-insurance model of the healthcare system, in particular, by the transformation of medical institutions into new organizational and legal forms. The process began with health care facilities that provide primary health care, thanks to which the private health services sector developed, which for the first time in the history of the health care system of Ukraine joined the provision of primary health care by concluding agreements with The National Health Service of Ukraine (NHSU). This process could be seen as an opportunity for development. At the same time, frequent changes in the leadership of the industry and elections to councils at various levels are unfavorable political conditions for the implementation of industry reform.

Only due to the fact that relative stability and political will to implement the reform at the primary level was observed for 3 years, its implementation took place. A similar primary medical care funding mechanism has been for more than 70 years in the UK, the National Health Service (NHS), which was established in 1948 to provide affordable healthcare for both poor and rich patients. The UK's NHS is primarily funded by general taxation, but the UK spends relatively little funds on health care as compared with other Western European countries, making it difficult to improve the quality of care [13]. NHSU is also financed by taxes of Ukrainian citizens, and the cost of medical care in our country is one of the lowest in Europe [14]. In European countries, each patient chooses his own doctor, concluding an agreement with him. In the Netherlands, the location of the patient is especially important - he must live within a 15-minute drive to the clinic in case of emergency, and a change of family doctor is possible no more than 1 time in 6 months [15]. At the same time, the territory of access to the outpatient clinic and the minimum period for which a declaration (agreement) with a doctor must be signed are not regulated in Ukraine.

To fulfill its functions and tasks, the Ministry of Health of Ukraine has approved a list of medical services and interventions, as well as laboratory and instrumental diagnostic tests performed within the framework of primary health care services [16]. This list is minimal, but sufficient for all types of primary health care services. It is also small in the vast majority of countries, but in case of necessities, additional interventions are provided, which are paid separately. For example, Canadian family physicians, as in Ukraine, receive a contribution for each patient, but they also receive incentives, bonuses, and special payments for 
specific health promotion services, such as diabetes care or smoking cessation. For the first time, telemedicine equipment was officially included in this list. In Norway telemedicine has been used since 1993 to provide medical care to patients living in the most remote areas [17]. Successful telemedicine projects are also available in Germany, Denmark, France, Italy, Finland, Poland, the implementation of which has already passed into the commercial field. Today, most American insurance companies have said they are willing to cover the cost of medical teleconsultation as well as clinic care, and for the uninsured, the cost of such a service will cost $\$ 45$ [18]. The number of teleconsultations in the United States will increase from 19.7 million in 2014 to 158.4 million in 2020 [18]. The low level of equipment, lack of experience, opportunities to consult with doctors of specialties, distrust of doctors and the public to consultations with telemedicine have led to the fact that even the existing telemedicine equipment is not constantly used for its intended purpose.

Thus, we have shown that the changes of the organization of the primary health care in Ukraine, which began from 2017 has opened up significant opportunities for quality work of facilities that provide primary health care due to the adoption of a number of regulations at the state level. Ways to introduce changes in the external and internal environment of primary health care facilities for prevention are the same with the introduction of similar processes in other countries.

\section{CONCLUSIONS}

1. It is shown that the introduction of a new organizational and legal form of health care facilities that provide primary care, on the basis of a number of regulations adopted at the state level, provided opportunities for enterprise development, as a factor of the external environment, which obliged the heads of enterprises to make timely management decisions to improve its material and technical condition in order to obtain funding through the conclusion of an agreement with the National Health Service of Ukraine. This was confirmed by significant changes in 2017: 100\% provision of equipment for the prevention and treatment of patients with cardiovascular diseases for the population of Zaporizhia region, which became a strong factor in the internal environment of the institution.

2. It is proved that during 2017-2019 years there was a high level of human resources of employees with secondary medical education in the Zaporozhye region on average $82.4(73.1 \div 91.8) \%$ the vast majority of whom are persons under the age of $45-62.0(54.9 \div 73.7) \%$, against the background of a significantly lower level of provision of primary care physicians $-66.1(59.25 \div 81.2) \%(\mathrm{p}<0.05)$, which is one of the weaknesses of the internal environment, especially in the presence of a threat in the form of an increase in the proportion of the population older than working age, which as of 01.2019 . reached $28.3 \%$.

3 . It is established that one of the threats to the external environment is the insufficient level of knowledge about the risk factors cardiovascular diseases among the adult population, especially among men in the group of $18-24$ years $(75.0 \%)$, indicating a lack of control over health policy and a healthy lifestyle for $55 \%$ of the adult population with gender differences ( $45.5 \%$ of men vs. $60 \%$ of women) with the free choice of a family doctor whose main work is preventive measures.

\section{REFERENCES}

1. Tkachenko V,I. Pervichnaya medicinskaya pomosh v mire: rezultaty 40-letnej realizacii Alma-Atinskoj deklaracii (1978) budushee razvitie soglasno Astaninskoj deklaracii (2018) [Primary care in the world: the results of the 40-year implementation of the Almaty Declaration (1978); future development according to the Astana Declaration (2018)] Semejnaya medicina. 2019; 4 (84):97-102. (In Russian).

2. «Pro kompleksni zakhody shchodo vprovadzhennia simeinoi medytsyny v systemu okhorony zdorovia» Postanovy Kabinetu Ministriv Ukrainy vid 20.06.2000 № 989 [The resolution of the Cabinet of Ministers of Ukraine № 989"About comprehensive measures for introducing family medicine into the health care system" from 20.06.2000 № 989] doi: https://zakon. rada.gov.ua/laws/show/989-2000-\%D0\%BF\#Text .

3. The WHO CVD Risk Chart Working Group World Health Organization cardiovascular disease risk charts: revised models to estimate risk in 21 global regions Lancet Glob Health. 2019; 7: 332-377. doi: https:// doi.org/10.1016/S2214-109X(19)30318-3.

4. Thomas A. Gaziano Growing Epidemic of Coronary Heart Disease in Lowand Middle Income Countries Curr Probl Cardiol. 2010; 35(2): 72-115. doi: 10.1016/j.cpcardiol.2009.10.002

5. Pro zatverdzhennya Primirnogo tabelya materialno-tehnichnogo osnashennya zakladiv ohoronizdorov'ya ta fizichnih osib - pidpriyemciv, yaki nadayut pervinnu medichnu dopomogu: Nakaz MOZ Ukrayini vid 26.01.2018 № 148. [About approval of the main content of material and technical support of the health care institution and individuals - entrepreneurs of primary health care: Order of the Ministry of Health of Ukraine from 26.01.2018 № 148] doi: https://moz.gov.ua/ uploads/0/4141-dn_20180126_148.pdf.

6. Metodika provedeniya SWOT-analiza. Obrazcy matric SWOT [Methods of conducting SWOT-analysis. Samples of SWOT matrices]. doi: https: //marketing.by/novosti-rynka / metodika-provedeniya-swot-analizaobraztsy-matrits-swot/.

7. Pro zatverdzhennya Polozhennya pro sistemu bezperervnogo profesijnogo rozvitku fahivciv u sferi ohoroni zdorov'ya: Postanova KMU vid 28.03.2018 № 302. [ the enactment of the order of the Cabinet of Ministers of March 28, 2018 № 302"About approval of the Regulations of the system of continuous professional development of specialists of health care" from 28.03.2018 № 302.] doi: https://www.apteka.ua/ article/455594.

8. Klimenko V.I., Kremsar I.M. Mediko - organizacijni problemi profilaktiki hvorob sistemi krovoobigu. [Medico - organizational problems of prevention of diseases of the circulatory system.] Suchasni aspekti medicini i farmaciyi. 2017; 1: 79-80. (In Ukrainian).

9. Pro zatverdzhennya Reyestru likars'kykh zasobiv, yaki pidlyahayut' reimbursatsiyi Postanova KMU vid 01.06.2020 № 1284. [On approval of the Register of medicinal plants that connect reimbursement Resolution of the Cabinet of Ministers of 01.06.2020 № 1284.]doi: https://moz. gov.ua/article/ministry-mandates/nakaz-moz-ukraini-vid-01062020-1284-pro-zatverdzhennja-reestru-likarskih-zasobiv-jaki-pidljagajutreimbursacii-stanom-na-28-travnja-2020-roku. 
10. Kovalenko V.N. Sravnitelnaya harakteristika profilaktiki serdechnososudistyh zabolevanij v Ukraine i Evrope po dannym issledovaniya EUROASPIRE IV: gospitalnaya liniya. [Comparative characteristics of the prevention of cardiovascular disease in Ukraine and Europe according to the study EUROASPIRE IV: hospital line.] Ukrayinskij kardiologichnij Journal. 2015; 4: 17-24. (In Russian).

11. Analiz regulyatornogo vplivu do proektu postanovi Kabinetu Ministriv Ukrayini «Deyaki pitannya realizaciyi derzhavnih finansovih garantij medichnogo obslugovuvannya naselennya za programoyu medichnih garantij na 2020 rik» [Analysis of the regulatory impact of the project on the establishment of the Cabinet of Ministers of Ukraine "Some issues of implementation of state financial guarantees for the provision of medical services to the population under the program of medical guarantees for 2020".]. doi: http://moz.gov.ua/uploads/3/15044pro_20191122_1_arv.pdf.

12. Poryadok viboru likarya, yakij nadaye pervinnu medichnu dopomogu : Nakaz MOZ Ukrayini vid 19.03.2018 № 503.[Procedure for selecting a doctor who provides primary care: Order of the Ministry of Health of Ukraine dated March 19, 2018 № 503.] doi: https://zakon.rada.gov.ua/ laws/main/z0347-18\#n22.

13. Ulrike N., Harris M.M. Atestaciya (ekspertne ocinyuvannya) likariv u Velikobritaniyi. [Certification (expert evaluation) of doctors in the UK] Semejnaya medicina. 2017; 4 (72): 31-34. (In Ukrainian).

14. Goroshko A., Shapoval N. Can people afford to pay for health care? doi: https://www.euro.who.int/__data/assets/pdf_file/0008/381590/ ukraine-fp-eng.pdf?ua $=1$.

15. Tkachenko V.I., Alekseichenko 0.I. General practice in Netherlands: professional training and organization of medical care. Semejnaya medicina. 2017; 3: 21-23.

16. Poryadok nadannya pervinnoyi medichnoyi dopomogi : Nakaz $\mathrm{MOZ}$ Ukrayini vid19.03.2018. № 504. [Procedure for the onset of primary medical care: Order of the Ministry of Health of Ukraine dated March 19, 2018. № 504.]. doi: https: // zakon.rada.gov.ua/laws/show/z0348$18 \#$ n19.
17. Gonalves M.R., Umpierre R.N. Expanding Primary Care Access: A Telehealth Success Story. The Annals of Family Medicine. 2017; 15 (4): 383. doi: https://doi.org/10.1370/afm.2086.

18. Choi Y. Telemedicine in the USA: Standardization through information management and technical applications May 2006 IEEE Communications Magazine. 44(4):41-48. doi: 10.1109/MCOM.2006.1632648.

"Scientific substantiation of optimization of the system of medical care in different levels to the adult population in the region aspect» (2016-2020, № state registration 0116U005353).

ORCID and contributorship:

Victoria I. Klymenko: 0000-0001-8053-2127 A,E,F

Iryna M. Kremsar: 0000-0002-9191-4937 B,C,D

\section{Conflict of interest:}

The Authors declare no conflict of interest.

\section{CORRESPONDING AUTHOR Iryna M. Kremsar}

Zaporizhzhia state medical university

3 Gagaryna St., 69005 Zaporizhzhia, Ukraine

tel: +380966727927

e-mail:kremsaririna@gmail.com

Received: 15.11 .2020

Accepted: 07.03.2021

A - Work concept and design, B - Data collection and analysis, C - Responsibility for statistical analysis,

$\mathbf{D}$-Writing the article, $\mathbf{E}$-Critical review, $\mathbf{F}$ - Final approval of the article 